\title{
Use of Augmented Reality App as a means of motivation for high secondary education in times of COVID-19
}

\section{Uso de App de Realidad aumentada como medio de motivación para la educación media superior en tiempos de COVID-19}

\author{
NAVARRERE-ARIAS, Dulce J.†*, HERNÁNDEZ-GARCÍA, Héctor Daniel and PÉREZ-BAUTISTA, \\ Mario
}

Instituto Tecnológico Superior del Occidente del Estado de Hidalgo, División de Ingeniería en Sistemas Computacionales, México

ID $1^{\text {st }}$ Author: Dulce J., Navarrete-Arias / ORC ID: 0000-0002-7915-068X, Researcher ID Thomson: AAR-8785-2021, CVU CONACYT ID: 366071

ID $1{ }^{\text {st }}$ Coauthor: Héctor Daniel, Hernández-García / ORC ID: 0000-0001-5261-8353, CVU CONACYT ID: 208146

ID $2^{\text {nd }}$ Coauthor: Mario, Pérez-Bautista / ORC ID: 0000-0002-3260-906X, CVU CONACYT ID: 638669

DOI: $10.35429 /$ JITC.2021.13.5.14.19

Received March 10, 2021; Accepted June 30, 2021

\section{Abstract}

As the COVID-19 health crisis continues, schools have been forced to close their doors, leading school systems to find innovative ways to reach and teach their students. A novel way of reaching students is Augmented Reality. High secondary level students have abandoned their studies and / or the idea of studying at a college, this derived from the methodology of teaching and monitoring their learning. The virtual environment developed in this research is intended to motivate the student of high secondary education of specialty related to the career of engineering in computer systems to continue with their studies at a college by showing them the applications that can develop themselves with the tools technologies and the knowledge to be acquired within the computer systems engineering study program. For this proposal, the Unity 3D software was used, since it presents flexibility for the creation of any type of environment. An initial and final survey was implemented after presenting the AR app to determine whether after its use the students feel motivated to continue with their studies.

COVID-19, Augmented Reality, Educational apps
Resumen

A medida que continúa la crisis sanitaria por la COVID19 , las escuelas se han visto en la obligación de cerrar sus puertas, conllevando a los sistemas escolares a encontrar formas innovadoras de llegar y enseñar a sus estudiantes. Una forma novedosa de hacerlo es la Realidad Aumentada. Los estudiantes de nivel media superior han abandonado sus estudios y/o la idea de estudiar a nivel superior, esto derivado de la metodología de impartición y seguimiento a su aprendizaje. El entorno virtual desarrollado en esta investigación, tienen la intención de motivar al alumno de educación media superior de especialidad afín a la carrera de ingeniería en sistemas computacionales a continuar con sus estudios a nivel superior al mostrarles las aplicaciones que ellos mismos pueden desarrollar con las herramientas tecnológicas y los conocimientos a adquirir dentro del programa de estudios de ingeniería en sistemas computacionales. Para esta propuesta, se utilizó el software Unity 3D, ya que presenta flexibilidad para la creación de cualquier tipo de entorno. Se implementó una encuesta inicial y final después de presentarles la app de AR para determinar si posteriormente de su uso los alumnos se sienten motivados en continuar con sus estudios.

COVID-19, Realidad Aumentada, Apps educativas

Citation: NAVARRERE-ARIAS, Dulce J., HERNÁNDEZ-GARCÍA, Héctor Daniel and PÉREZ-BAUTISTA, Mario. Use of Augmented Reality App as a means of motivation for high secondary education in times of COVID-19. Journal of Information Technologies and Communications. 2021. 5-13: 14-19

\footnotetext{
$\dagger$ Researcher contributing as first author
} 


\section{Introducción}

Currently, society is confined to its homes due to the health crisis caused by COVID-19 and there is uncertainty as to when it will be possible to return to normality. Due to this, it is essential to adapt to the new dynamics of life and to the use of technological tools that allow, while safeguarding personal integrity, to resume the activities that were carried out on a daily basis. School and work activities have been affected (Reeves, Lang, \& Carlsson-Szlezak, 2020). In Mexico, since March 20, 2020, a health emergency was declared, therefore, before this resolution, the educational centers closed their facilities.

Suspending academic activities in such a sudden and unexpected way, caused a rapid transition of the educational system in which, now the "face-to-face" teaching-learning process turned to an "online" model. This new scheme has had to be launched with little preparation time, without having a suitable strategic planning for this new work modality (GarcíaPeñalvo, Corell, Abella-García, \& Grande, 2020), there is no doubt that before A normal scenario for the teaching of online classes, the ideal would be to redesign each of the subjects taught and taken in person in a distance format, making a consensus to ensure that all actors have the minimum required electronic means, necessary digital skills and a positive disposition to change.

On the other hand, due to the deficiencies in the technological skills of teachers and as mentioned above, the lack of planning for this new scheme derived from reaction time, some situations have emerged that slow down or cancel the learning process of the students, i) accessibility: not all the population has the necessary resources such as internet or electronic devices to receive classes, ii) usage time: people who do have technological equipment have to share the resource with another member of the family, iii) training: related to the limited ability and knowledge on the part of students and teachers to use videoconferencing platforms and LMS platforms based on the Cloud, as well as to impart knowledge through digital content, and iv) predisposition: concerning the will to students and teachers to get involved with technological devices and tools for the acquisition of knowledge (Enguita, 2020).
The present work is focused on students of the sixth semester of upper secondary level, this being the last semester before making a decision of which career to choose and in which institution to continue with their studies. Before the pandemic there were already problems such as failure and abandonment, with the health emergency that we are going through, school dropouts have skyrocketed and consequently upper secondary students do not continue with their professional training. According to data presented by INEGI in its press release on March 23, 2021 for reasons associated with COVID-19 or due to lack of money or resources, 5.2 million people in Mexico did not enroll in the 2020-2021 school year.

There are several variables that can be attributed to this dropout, such as lack of interest in studying, lack of motivation in the face of the new teaching scheme and / or financial deficiencies. This article shows the implementation of a mobile application with Augmented Reality that allows sixth semester students of upper secondary education in specialties related to computer systems engineering, to visualize virtual elements that are combined with the physical environment as a medium. motivation to continue with higher level studies. The proposed application allows, through Unity, to display in an attractive and innovative way textual information about the entrance process to the educational program of engineering in computer systems. The purpose of this experiment is to motivate students to continue with their higher-level studies by visualizing and understanding the application programming and its functions.

\section{Augmented reality in education}

It is feasible to think that we are in a process of consolidation of different trends of emerging technologies within the educational context, such as mobile devices, 3D modeling and augmented reality ("Augmented Reality") (AR). Augmented reality seeks to enrich the physical world by integrating virtual elements under an interactive environment, in which it is possible to interact in real time through different technological devices, ranging from tablets, smartphones, to special glasses. This reality has the following characteristics (Prendes Espinosa, 2014):

1. Combine the real and the virtual

2. Interact in real time

NAVARRERE-ARIAS, Dulce J., HERNÁNDEZ-GARCÍA, Héctor Daniel and PÉREZ-BAUTISTA, Mario. Use of Augmented Reality App as a means of motivation for high secondary education in times of COVID-19. Journal of of motivation for high secondary education in times of
Information Technologies and Communications. 2021 


\section{Register in 3D}

On the other hand, Prendes (2014) mentions that augmented reality has different levels that are summarized as follows:

Level 0 (Hyperlinked): This is characterized by not having threedimensional elements or a record of bookmarks and, basically, it is hyperlinks to other content. This level makes use of barcodes, QR codes, and random image recognition to link.

- $\quad$ Level 1 (Marker-based): At this level, two-dimensional pattern recognition and 3D objects are recognized. The markers you use can be plain, asymmetrical black and white images. This is the level that has been used in the educational field in recent years, since from an image that the virtual object of study is recognized and visualized.

- $\quad$ Level 2 (Without markers): It uses the GPS of the mobile device and based on the location and orientation; points of interest are superimposed on real images. At this level, applications can use the accelerometer to calculate the incline and react to it.

- $\quad$ Level 3 (Augmented vision): This AR is immersive, since it makes use of special displays that the user must wear, such as the use of glasses, instead of the screen of the mobile device.

The appearance of augmented reality in the educational field has facilitated, through tablets and mobile phones, the promotion of innovative teaching strategies, as well as influencing interest and positive motivation based on augmented reality (Reyes, 2020). Studies show that experiences with interaction for the assimilation of knowledge within the classroom are related to an increase in academic performance (Cabrero Almenara \& Barroso Osuna, 2016), also with a positive acceptance by students to use reality applications increased in learning (Lagunes, Torres, Angúlo \& Martínez, 2017), as well as to assess with high levels of satisfaction participation in the training experience with strategies that involve the simulation of reality (Fonseca, Redondo \& Valls, 2016).
In education, augmented reality is an emerging and transformative technology with a great impact since it allows the creation of content by the teacher to later show the students, these contents present characteristics of interactivity and three-dimensionality, allowing the enrichment of printed materials for students. students with additional virtual information. Augmented reality is versatile since it can be used in different subjects and disciplines, encouraging students to motivate them to generate their own learning objects (Blas, Vázquez, Morales \& López, 2019).

In higher-level education, the use of ICT has become a fundamental issue, since from it it is sought to design digital teaching tools in order to incorporate knowledge-generating elements for the representation and analysis of concepts and reality, in addition to adding to meaningful learning for students (Fernández, Sánchez \& Calatayud, 2018). 21st century education considers augmented reality an emerging technology with a high possibility of impacting the teaching-learning process, since it offers various educational guides and great potential to improve meaningful learning by students (Almenara, Vázquez-Cano, Meneses \& Martínez, 2020).

\section{Methodology}

\section{Interface development}

The virtual environment developed in this research is intended to show that through a configuration within the Unity development environment and programming, virtual objects can be created to interact with the physical environment, applications that can be created for any type of environment.

The proposed application has the following interaction scheme with the student, i) start: here the student must run the application and focus the camera of their device on the target image, immediately a text is displayed that shows the requirements to process a file at the Tecnológico Superior del Occidente of the State of Hidalgo (ITSOEH), ii) later the student can click on the two virtual buttons that are presented, the first is to go to the social network Facebook of the computer systems engineering degree belonging to to ITSOEH and the second directs them to the official ITSOEH website (see Figure 1). 


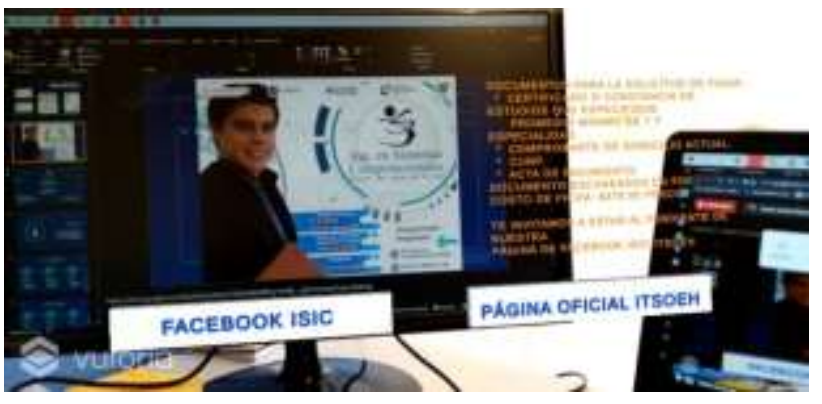

Figure 1 RA Scene Screen

Reference Source: Own Elaboration

\section{Development of the experiment}

The experiment focuses on sixth semester students from upper secondary educational units in the area of influence of the Higher Technological Institute of the West of the State of Hidalgo. ITSOEH is an educational center that offers quality education, which guides its students to become ethical professionals, maintaining a curriculum according to the student's necessary learning for their incorporation into the work environment. However, derived from the health crisis in which we are living, teachers of all educational levels have seen the need to migrate their face-to-face classes to a remote-virtual way, adapting methodologies and tools in which they had little knowledge.

As a result of this situation, it has been identified that students from upper secondary education centers no longer wish to continue with their professional studies, this can be established by detecting the abandonment of studies in the sixth semester and by not processing an entry form in any higher education campus.

The objective of this research is to compare with an initial and a final survey applied to sixth semester students in upper secondary education to know the degree of motivation of students to continue with their university studies in a profile of computer systems engineers. To measure the motivation of the students for the use of the application, an online survey was implemented through a Google form, which consisted of 10 questions with multiple-choice answers on the Likert scale (totally agree, up to totally disagree). The questions focused on the aspects of motivation and satisfaction; this last aspect included elements related to the user experience.

\section{Results}

In total, the experiment was carried out in 5 upper secondary institutions where the student was given a talk about the operation of the augmented reality application and what was the development to create it, after the talk, they were provided with the installer (apk) so that they themselves installed the application on their cell phone and could interact with the app. In total, 78 students were involved in this process. Defining those 78 students was the population that participated in the total of the talks.

As can be seen in Figures 2 and 3, the students responded positively as to whether the use of the AR app motivates them to continue with their studies at a higher level and in satisfaction, we obtained a positive response by approaching this knowledge in an attractive way, easy to use and easy to understand.

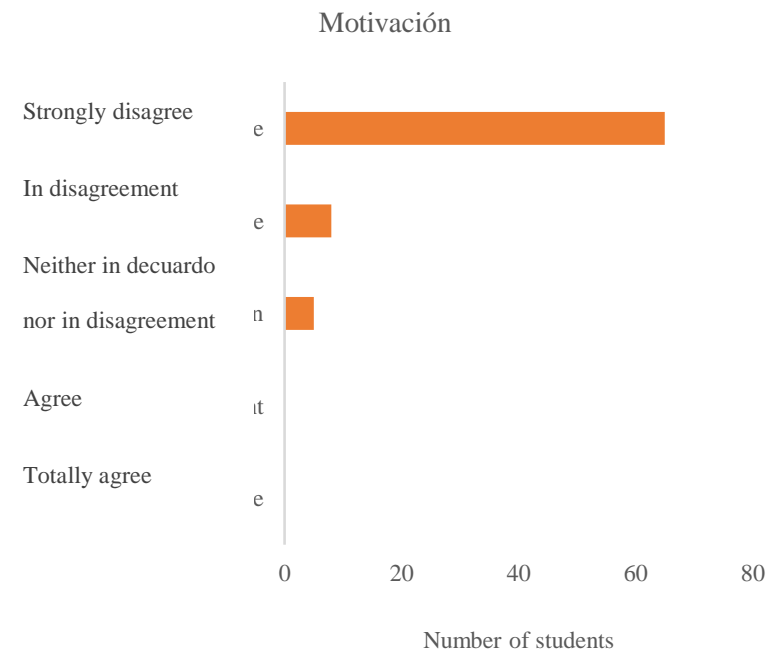

Figure 2 Student's perception of whether the AR app motivates them to continue with their higher-level studies Reference source: Own elaboration

\section{Satisfaction}

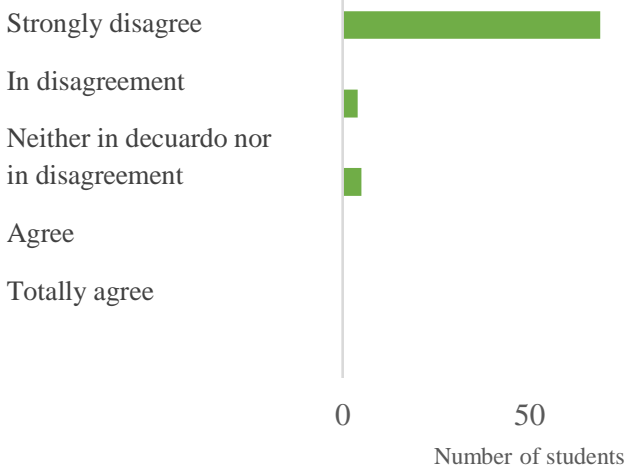

100

Figure 3 Student's perception of their degree of satisfaction with the operation of the AR app Reference Source: Own Elaboration 
In addition, at the end of the questionnaire an open question was included where it was possible to collect information regarding comments on the application to later implement a word cloud that helps us find the descriptive words of the comments made by the students. In Figure 4 we can visualize this word cloud, from which we can rescue which programs, exciting, knowing, interesting and learning are the largest words, therefore they have the highest frequency in the responses of the students.

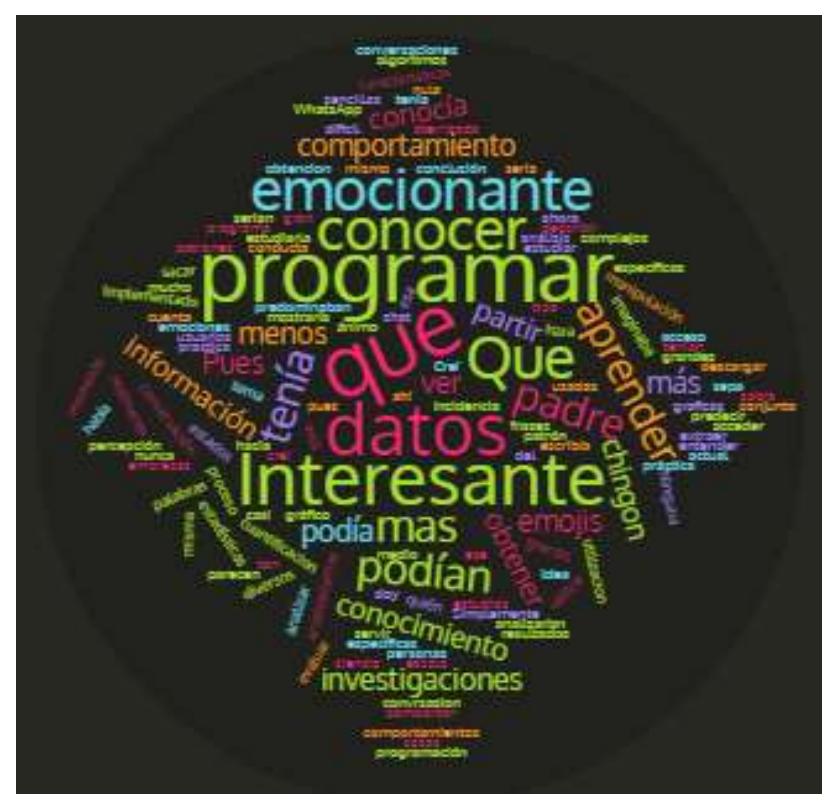

Figure 4 Word cloud in relation to the perspective of the students regarding the AR app

Reference Source: Own Elaboration

\section{Conclusions}

The objective of this study was to develop a mobile application for the Android operating system that uses augmented reality to motivate upper secondary students to continue their studies at a higher level within the area of computer systems. The results obtained reflect that the student finds it interesting to know how the application works through programming.

On the other hand, it would be very positive to implement this motivational technique with augmented reality applications in programming subjects within the ITSOEH, in order to corroborate that augmented reality has a decisive influence on taking in a positive way the knowledge that makes us tedious or complicated when time to study.

\section{References}

Almenara, J. C., Vázquez-Cano, E., Meneses, E. L., \& Martínez, A. J. (2020). Posibilidades formativas de la tecnología aumentada. Un estudio diacrónico en escenarios universitarios. Revista complutense de educación, 31(2), 141152.

Blas, D., Vázquez, E., Morales, B \& López, E. (2019). Uso de apps de realidad aumentada en las aulas universitarias. Campus Virtuales, 8(1), 37-48.

Cabero Almenara, J., \& Barroso Osuna, J. (2016). Ecosistema de aprendizaje con «realidad aumentada»: posibilidades educativas. Revista Tecnología, Ciencia y Educación, 5(5), 141154.

Enguita, F. (2020). Una pandemia imprevisible ha traído la brecha previsible. Retrieved from https://blog.enguita.info/2020/03/una-

pandemia-imprevisible-ha-traidola.html

Fernández, I. M. S., Sánchez, J. L. S., \& Calatayud, V. G. (2018). Entornos Personales de Aprendizaje para la comprensión y desarrollo de la Competencia Digital: análisis de los estudiantes universitarios en España. Educatio Siglo XXI, 36(2 Jul-Oct), 115-134.

Fonseca, D., Redondo, E. \& Valls, F. (2016). Motivación y mejora académica utilizando realidad aumentada para el estudio de modelos tridimensionales arquitectónicos. Education in the Knowledge Society. EKS, 17(1), 45-64. http://dx.doi.org/10.14201/eks2016171

García-Peñalvo, F. J., Corell, A., Abella-García, V., \& Grande, M. (2020). Online Assessment in Higher Education in the Time of COVID-19. Education in the Knowledge Society (EKS), 21, $1-26$.

Lagunes, A., Torres, C., Angúlo, J. \& Martínez, M. (2017). Prospectiva hacia el Aprendizaje Móvil en Estudiantes Universitarios. Formación universitaria, $\quad 10(1), \quad 101-108$. http://dx.doi.org/10.4067/S071850062017000100011

Prendes Espinosa, C. (2014). Realidad aumentada y educación: análisis de experiencias prácticas. Píxel-Bit. Revista de Medios y Educación, 46, 187-203. 
Reeves, M., Lang, N., \& Carlsson-Szlezak, P. (2020). Lead Your Business Through the Coronavirus Crisis. Harvard Business Review, 6-11.

Reyes, C. E. (2020). Percepción de estudiantes de bachillerato sobre el uso de Metaverse en experiencias de aprendizaje de realidad aumentada en matemáticas. Pixel-Bit, Revista De Medios Y Educación, (58), 143-159. doi:10.12795/pixelbit.74367 